Volume 2 Nomor 2, Desember 2019

E-ISSN : 2655-7347

\title{
KEWENANGAN NOTARIS DALAM HAL MEMBUAT AKTA PARTIJ (CONTOH KASUS PUTUSAN MAHKAMAH AGUNG NOMOR: 1003 K/PID/2015)
}

\author{
Rio Utomo Hably \\ (Mahasiswa Program S1 Fakultas Hukum Universitas Tarumanagara)
}

(E-mail: Riohably88@gmail.com)

\section{Dr. Gunawan Djajaputra, S.H., S.S., C.N., M.H. \\ (Corresponding Author)}

(Dosen Tetap Fakultas Hukum Universitas Tarumanagara, Meraih Sarjana Hukum dari Fakultas Hukum Universitas Tarumanagara (1991), Magister Hukum dari Fakultas Hukum Universitas

(E-mail: gunawandjajaputra@fh.untar.ac.id)

\begin{abstract}
Partij deed is a type of deed that can be made by a notary public official who is authorized by the state to perform services in society. Notary public as a public official who contains an authentic description of all events or events that are seen, experienced, and witnessed by the Notary himself. Notary Deed must contain what is desired by both parties in the agreement. The notary public only has the role of providing perfect proof of strength through the deed he made if later the parties to the deed disputed in court. In practice problems often arise including the issue of notary responsibility and notary authority as happened in the deed of party, how the authority of the Notary in Making Partij Deed (Example of Supreme Court Decision Case Number: 1003 K / PID / 2015) is a problem that is discussed. Descriptive research methods, using secondary data and primary data as supporting data, are analyzed qualitatively. The results of the study illustrate that the Notary does not follow under Law of the Republic of Indonesia Number 2 of 2014 concerning Amendments to Law Number 30 of 2004 concerning the Position of Notary.
\end{abstract}

Keyword: Authority of a Notary, deed Partij.

\section{PENDAHULUAN}

\section{A. Latar Belakang}

Akta partij merupakan salah satu jenis akta yang dapat dibuat oleh Notaris sebagai pejabat umum yang diberi kewenangan oleh negara untuk melakukan pelayanan di masyarakat. Akta partij dapat didefinisikan sebagai akta yang dibuat di hadapan Notaris, suatu akta yang dibuat berdasarkan keterangan atau perbuatan pihak yang menghadap Notaris, dan keterangan atau perbuatan itu agar dikonstatir oleh Notaris untuk dibuatkan akta. Selain 
Volume 2 Nomor 2, Desember 2019

E-ISSN : 2655-7347

akta partij, maka Notaris juga membuat akta relaas, yaitu akta yang dibuat oleh Notaris sebagai pejabat umum yang memuat uraian secara autentik tentang semua peristiwa atau kejadian yang dilihat, dialami, dan disaksikan oleh Notaris sendiri. Definisi akta partij dan akta relaas tersebut sebenarnya telah dinyatakan secara eksplisit pada Pasal 15 Ayat (1) Undang-Undang Nomor 2 Tahun 2014 tentang Jabatan Notaris, yang menyatakan bahwa "Notaris berwenang membuat akta autentik mengenai semua perbuatan, perjanjian, dan penetapan yang diharuskan oleh peraturan perUndangUndangan dan/atau yang dikehendaki oleh yang berkepentingan untuk dinyatakan dalam akta autentik, menjamin kepastian tanggal pembuatan akta, menyimpan akta, memberikan grosse, salinan dan kutipan akta, semuanya itu sepanjang pembuatan akta itu tidak juga ditugaskan atau dikecualikan kepada pejabat lain atau orang lain yang ditetapkan oleh Undang-Undang". Notaris dalam membuat akta partij hanya sebagai pihak penengah dan membuat akta berdasarkan keinginan dari kedua belah pihak. Pejabat notaris fungsinya hanya mencatatkan (menuliskan) apa yang dikehendaki oleh para pihak yang menghadap Notaris tanpa ada kewajiban baginya untuk menyelidiki secara materiil hal-hal yang dikemukakan oleh penghadap kepadanya. Akta yang dihasilkan Notaris sebagai pejabat umum merupakan akta autentik yang berbeda dengan akta yang dibuat oleh para pihak yang berkepentingan tanpa disertai keberadaan Notaris.

Akta autentik ini merupakan alat bukti terkuat dan terpenuh yang mempunyai peran penting dalam setiap hubungan hukum dalam kehidupan masyarakat dimana pada hakekatnya, akta seperti ini memuat kekuatan pembuktian baik lahiriah, formil, maupun materiil (uit bewijskracht, formiele en materiele bewijskracht). Sebagaimana telah dinyatakan di atas, Notaris hanya sebagai penengah. Akta yang dihasilkan oleh Notaris pada dasarnya adalah atas dasar kesepakatan kedua belah pihak yang berkepentingan, sehingga dengan demikian akta Notaris dapat dikatakan sebagai salah satu bentuk perjanjian. Perjanjian memiliki kaitan yang sangat erat dengan perikatan dimana perikatan adalah suatu perhubungan hukum antara dua 
Volume 2 Nomor 2, Desember 2019

E-ISSN : 2655-7347

orang atau dua pihak, berdasarkan mana pihak yang satu berhak menuntut sesuatu hal dari pihak yang lain, dan pihak yang lain berkewajiban untuk memenuhi tuntutan itu, sementara perjanjian adalah suatu peristiwa dimana seorang berjanji kepada seorang lain atau dimana dua orang saling berjanji untuk melaksanakan sesuatu hal.

Dengan demikian dapat disimpulkan bahwa suatu perjanjian menimbulkan adanya suatu perikatan antara dua orang yang membuatnya, perjanjian adalah sumber perikatan disamping sumber yang lain. Suatu perjanjian juga dinamakan persetujuan karena dua pihak itu setuju untuk melakukan sesuatu sehingga dapat dikatakan bahwa perjanjian dan persetujuan adalah sama artinya. Perikatan adalah suatu pengertian abstrak sementara perjanjian adalah suatu hal yang kongkrit atau suatu peristiwa nyata.

Salah satu syarat sahnya perjanjian menurut Pasal 1320 Kitab UndangUndang Hukum Perdata (KUHPerdata) adalah adanya kesepakatan. Kesepakatan, yang merupakan pernyataan kehendak para pihak merupakan salah satu syarat penting akan sahnya suatu akta. Perjanjian hanya dapat timbul dengan kerja sama dari dua orang atau lebih atau perjanjian (akta) "dibangun" oleh perbuatan dari beberapa orang, karenanya perjanjian digolongkan sebagai perbuatan hukum berganda. Pengertian sepakat dilukiskan sebagai pernyataan kehendak yang disetujui (overeenstemende wil verklaring) antara pihak-pihak, pernyataan pihak yang menawarkan dinamakan penawaran (aanbad) sedangkan pernyataan pihak yang menerima penawaran dinamakan akseptasi (acceptie). Penawaran berlangsung dalam proses yang diwujudkan dalam bentuk kata-kata dan dapat juga dalam bentuk perilaku. Penawaran yang diikuti dengan penerimaan bersama-sama melahirkan perjanjian.

Berdasarkan penjabaran singkat di atas, dapat dikatakan bahwa akta Notaris harus berisi apa yang diinginkan oleh kedua belah pihak yang ada dalam perjanjian (akta) tersebut. Notaris hanya berperan memberikan kekuatan pembuktian sempurna melalui akta yang ia buat apabila kelak para 
Volume 2 Nomor 2, Desember 2019

E-ISSN : 2655-7347

pihak dalam akta tersebut bersengketa di pengadilan. Apabila dalam akta tersebut terdapat klausul atau isi yang hendak diubah, maka Notaris harus mendapat persetujuan dari pihak-pihak dalam akta agar perubahan tersebut dapat memenuhi unsur sepakat sehingga kelak akta tidak dapat dimintakan pembatalan oleh pihak yang merasa dirugikan. Lembaga notariat adalah salah satu lembaga kemasyarakatan yang timbul dari kebutuhan dalam pergaulan sesama manusia yang menghendaki adanya suatu alat bukti mengenai hubungan hukum keperdataan yang ada dan atau terjadi di antara mereka. Masyarakat menaruh kepercayaan yang sangat tinggi terhadap para Notaris yang dianggap sebagai solusi bagi masalah ketidakjelasan di bidang hukum perdata. Undang-Undang tentang Jabatan Notaris sendiri telah memberikan label pejabat umum kepada seorang Notaris sehingga sebagai seorang pejabat umum, Notaris memiliki kewajiban untuk melakukan pelayanan kepada masyarakat yang membutuhkan dengan sebaik-baiknya. Tujuan pokok dan utama dari hukum adalah ketertiban, dimana kebutuhan akan ketertiban ini merupakan syarat pokok (fundamental) bagi adanya masyarakat manusia yang teratur Hukum itu mengabdi pada tujuan negara, yaitu mendatangkan kebahagiaan dan kemakmuran para rakyatnya.

Oleh karena itu, Notaris sebagai pihak yang diberi kepercayaan oleh masyarakat dan diangkat sebagai pejabat umum oleh negara harus membantu tercapainya tujuan dibentuknya hukum itu sendiri mengingat Indonesia adalah sebuah negara hukum. Dalam melaksanakan tugasnya sehari-hari, Notaris dibatasi oleh aturan yang mengatur tentang profesinya, yaitu UndangUndang tentang Jabatan Notaris dan Kode Etik Notaris. Segala tindakan dan pelaksanaan tugas seorang Notaris harus sesuai dengan ketentuan-ketentuan yang ada di dalam aturan tersebut.

Ketidakpatuhan terhadap Undang-Undang maupun kode etik yang mengikatnya dapat memberikan akibat hukum yang harus ditanggung oleh Notaris yang melakukan pelanggaran. Kasus Notaris X di Pekanbaru adalah contohnya. Notaris X didatangi oleh Daniel selaku Direktur PT. Bonita Indah dan Bonar untuk meminta dibuatkan perjanjian kerjasama untuk mengikuti 
Volume 2 Nomor 2, Desember 2019

E-ISSN : 2655-7347

tender pengadaan 210 (dua ratus sepuluh) unit mobil ringan tanpa pengemudi yang akan disewakan ke PT Chevron Pasifik Indonesia dimana Daniel menyediakan perusahaannya, yaitu PT. Bonita Indah sementara Bonar dan Mangapul memasukkan modal. Inti dari kasus ini adalah Notaris yang bersangkutan melakukan perubahan terhadap minuta akta hanya tanpa persetujuan dan pengetahuan pihak pertama, pengubahan mana dilakukan setelah minuta ditandatangani oleh para penghadap, saksi, dan Notaris. Notaris juga dalam melakukan perubahan atau yang dikenal dengan renvoi tidak mengikuti tata cara sebagaimana diatur dalam peraturan perUndangUndangan.

Berdasarkan putusan yang telah inkracht van gewijsde (berkekuatan hukum tetap tersebut, tampak bahwa terdapat perbuatan seorang Notaris yang merupakan pejabat umum yang mendapatkan kepercayaan sangat besar dari masyarakat dan diharap sebagai solusi bagi masalah ketidakjelasan di bidang hukum perdata, melaksanakan tugasnya tidak sesuai dengan peraturan PerUndang-Undangan yang membatasi kewenangannya dalam menjalankan tugas sehari-hari sehingga menimbulkan kerugian bagi salah satu pihak karena melakukan perubahan isi dalam akta tanpa sepengetahuan pihak tersebut. Maka dari itu penulis tertarik untuk mendalami tentang Kewenangan Notaris Dalam Hal Membuat Akta Partij (Contoh Kasus Putusan Mahkamah Agung Nomor: 1003 K/PID/2015).

\section{B. Permasalahan}

Berdasarkan latar belakang masalah sebagaimana telah diuraikan di atas, maka Penulis merumuskan permasalahan sebagai berikut yaitu:

Bagaimana Kewenangan Notaris dalam hal membuat akta partij (contoh Kasus Putusan Pengadilan Mahkamah Agung Nomor: 1003/K/PID/2015)?.

\section{Metode Penelitian}

Menurut Soerjono Soekanto, penelitian hukum merupakan suatu bentuk kegiatan ilmiah, yang didasarkan pada metode, sistematika, dan pemikiran tertentu, yang bertujuan untuk mempelajari suatu atau beberapa gejala hukum 
Volume 2 Nomor 2, Desember 2019

E-ISSN : 2655-7347

tertentu, dengan jalan menganalisisnya. Di samping itu, juga diadakan pemeriksaan yang mendalam terhadap suatu faktor hukum tersebut, untuk kemudian mengusahakan suatu pemecahan atas permasalahan-permasalahan yang timbul di dalam gejala yang bersangkutan.

\section{Jenis Penelitian}

Penelitian normatif merupakan penelitian hukum yang dilakukan dengan cara meneliti bahan pustaka atau data sekunder. Penelitian hukum normatif disebut juga penelitian hukum doktrinal. Pada penelitian hukum jenis ini, sering kali hukum dikonsepkan sebagai apa yang tertulis dalam peraturan perundang-undangan atau hukum dikonsepkan sebagai kaidah atau norma yang merupakan patokan berperilaku manusia yang dianggap pantas.

\section{E. Sifat Penelitian}

Penelitian ini menggunakan jenis spesifikasi penelitian yang bersifat preskriptif, di mana Penulis memberikan argumentasi atas hasil yang diperolehnya. Argumentasi tersebut dapat berupa preskriptif atau penilaian berupa benar atau salah, atau apa yang seyogyanya menurut hukum terhadap fakta atau peristiwa hukum dari peristiwa hukum dari hasil penelitian.

\section{F. Jenis Data}

Adapun dari judul tersebut dapat ditarik jenis data sekunder yang merupakan kerangka konseptual dari penulisan hukum ini yang terdiri dari:

1. Kitab Undang-Undang Hukum Perdata (BW);

2. Undang-Undang Republik Indonesia Nomor 2 Tahun 2014 Tentang Perubahan Atas Undang-Undang Nomor 30 Tahun 2004 Tentang Jabatan Notaris

3. Putusan Pengadilan Mahkamah Agung Nomor: 1003/K/PID/2015.

a. Bahan Hukum Sekunder

Bahan hukum sekunder dapat berupa semua publikasi tentang buku atau jurnal hukum, hasil penelitian, hasil wawancara dengan narasumber atau ahli hukum sebagai upaya mendapatkan pendapat hukum tentang obyek yang Penulis teliti.

b. Bahan Non Hukum 
Volume 2 Nomor 2, Desember 2019

E-ISSN : 2655-7347

Yang berisi tentang kamus hukum, ensiklopedia hukum, bukubuku non hukum yang mengacu kepada Bahan Hukum Primer dan Sekunder, gunakan sebagai bahan untuk mendapatkan informasi, ataupun pendapat mengenai obyek yang Penulis teliti.

\section{G. Teknik Pengumpulan Data}

Teknik pengumpulan data yang Penulis gunakan dalam penelitian ini adalah dengan studi kepustakaan yang dilakukan melalui pengumpulan dari data sekunder di mana data yang diperolehnya dari bahan-bahan pustaka seperti buku-buku dan dokumen-dokumen tertulis lainnya.

\section{H. Teknik Pengolahan Data}

Teknik pengolahan data yang Penulis gunakan dalam penelitian ini adalah jenis Klasifikasi yang mana Penulis akan mengolah data yang sudah dikumpulkan sebelumnya, lalu Penulis akan menyusun data-data tersebut secara runtut, tersusun dan sistematis ke dalam jenis yang sama, sehingga memudahkan peneliti dalam melakukan analisis.

\section{Teknik Analisis Data}

Analisis data yang digunakan yaitu analisis kualitatif, yaitu menguraikan dan menginterpretasikan data dalam bentuk kalimat yang baik dan benar untuk memperoleh jawaban singkat yang dirumuskan secara deduktif.

\section{PEMBAHASAN}

\section{A. Data Penelitian}

Notaris adalah pejabat umum yang berwenang untuk membuat akta autentik dan memiliki kewenangan lainnya sebagaimana dimaksud dalam Undang-Undang ini atau berdasarkan Undang-Undang lainnya. Berdasarkan pengertian-pengertian tersebut dapat disimpulkan bahwa profesi Notaris adalah suatu profesi yang bergengsi dan mulia dimana untuk dapat menjadi Notaris seseorang harus diangkat oleh negara menjadi pejabat umum dan tugas dan kewenangan utama yang ada pada Notaris yaitu membantu masyarakat di bidang hukum keperdataan (privat). 
Volume 2 Nomor 2, Desember 2019

E-ISSN : 2655-7347

Lembaga notariat adalah salah satu lembaga kemasyarakatan yang timbul dari kebutuhan dalam pergaulan sesama manusia yang menghendaki adanya suatu alat bukti mengenai hubungan hukum keperdataan yang ada dan atau terjadi di antara mereka. Profesi Notaris menjadi bagian penting dari negara Indonesia yang menganut prinsip negara hukum sebagaimana diamanatkan Pasal 1 Ayat (3) Undang-Undang Dasar Negara Republik Indonesia tahun 1945.

Dengan adanya prinsip ini, negara menjamin terwujudnya salah satu fungsi hukum, yaitu kepastian hukum dan salah satu cara mencapai fungsi tersebut adalah menetapkan alat bukti yang menentukan dengan jelas hak dan kewajiban seseorang sebagai subjek hukum dalam masyarakat.

Selain itu, untuk kepentingan pelaksanaan tugas jabatan Notaris, dikenal asas-asas yang diadopsi dari asas pemerintahan yang baik, yaitu sebagai berikut: ${ }^{1)}$

a. Asas persamaan

Pada awal kehadiran Notaris di Indonesia, kewenangannya terbatas dan hanya melayani golongan penduduk tertentu atau melayani mereka yang bertransaksi dengan pihak Vereenigde Oost Indische Compagnie (VOC). Pada masa pemerintah Hindia Belanda, Notaris pernah diberi kewenangan membuat akta peralihan untuk bidang tanah yang tunduk kepada ketentuan-ketentuan Burgerlijk Wetboek dan tanah-tanah terdaftar, dimana peralihan haknya harus dilakukan dan didaftarkan pada pejabat-pejabat yang disebut Pejabat-pejabat Balik Nama (overschrijving ambtenaren). Sesuai perkembangan zaman, institusi Notaris telah menjadi bagian dari masyarakat Indonesia, dan dengan lahirnya Undang-Undang Jabatan Notaris, institusi Notaris semakin ditegaskan dan dinyatakan bahwa dalam

\footnotetext{
1) Ibid., hal.8.
} 
Volume 2 Nomor 2, Desember 2019

E-ISSN : 2655-7347

memberikan pelayanan kepada masyarakat Notaris tidak membeda-bedakan satu dengan yang lainnya, bahkan dalam keadaan tertentu, Notaris wajib memberikan jasa hukum di bidang kenotariatan secara cuma-cuma pada pihak yang tidak mampu.

b. Asas kepercayaan

Jabatan Notaris merupakan jabatan kepercayaan yang dengan demikian harus selaras dengan mereka yang menjalankan tugas jabatan Notaris, sebagai orang yang dapat dipercaya. Salah satu bentuk perwujudan Notaris sebagai jabatan kepercayaan adalah Notaris mempunyai kewajiban untuk merahasiakan segala sesuatu mengenai akta yang dibuatnya dan segala keterangan yang diperolehnya guna pembuatan akta sesuai dengan sumpah/janji jabatan yang diucapkannya, kecuali Undang-Undang menentukan lain. Notaris memiliki hak ingkar yang dapat dikatakan sebagai kewajiban ingkar karena dimuat sebagai salah satu kewajiban Notaris menurut Undang-Undang Jabatan Notaris. Notaris mempunyai kewajiban ingkar bukan untuk kepentingan diri Notaris, tetapi untuk kepentingan para pihak yang telah mempercayakan kepada Notaris, bahwa Notaris dipercaya oleh para pihak mampu untu menyimpan semua keterangan atau pernyataan para pihak yang pernah diberikan di hadapan Notaris yang berkaitan dalam pembuatan akta.

c. Asas kepastian hukum

Notaris dalam menjalankan tugas jabatannya wajib berpedoman secara normatif kepada aturan hukum yang berkaitan dengan segala tindakan yang akan diambil untuk kemudian dituangkan dalam akta. Notaris berdasarkan aturan hukum yang berlaku akan memberikan kepastian 
Volume 2 Nomor 2, Desember 2019

E-ISSN : 2655-7347

kepada para pihak bahwa akta yang dibuat di hadapan atau oleh Notaris telah sesuai dengan aturan hukum yang berlaku.

d. Asas kecermatan

Notaris dalam mengambil suatu tindakan harus dipersiapkan dan didasarkan pada aturan hukum yang berlaku. Notaris meneliti semua bukti yang harus diperlihatkan kepadanya dan mendengarkan keterangan atau pernyataan para pihak sebagai bahan dasar untuk dituangkan dalam akta.

e. Asas pemberian alasan

Setiap akta yang dibuat di hadapan atau oleh Notaris harus mempunyai alasan dan fakta yang mendukung untuk akta yang bersangkutan atau ada pertimbangan hukum yang harus dijelaskan kepada para pihak.

f. Larangan bertindak sewenang-wenang

Notaris dalam menjalankan tugas jabatannya dapat menentukan bahwa tindakan para pihak dapat dituangkan dalam bentuk akta Notaris atau tidak. Sebelum sampai pada keputusan tersebut, Notaris harus mempertimbangkan dan melihat semua dokumen yang diperlihatkan pada Notaris. Dalam hal ini Notaris mempunyai peranan untuk menentukan suatu tindakan dapat dituangkan dalam bentuk akta atau tidak, dan keputusan yang diambil harus didasarkan pada alasan hukum yang harus dijelaskan kepada para pihak.

g. Asas proporsionalitas

Notaris dalam menjalankan tugas jabatannya wajib bertindak menjaga kepentingan para pihak yang terkait dalam perbuatan hukum. Dalam menjalankan tugas jabatan, Notaris wajib mengutamakan adanya keseimbangan antara hak dan kewajiban para pihak yang menghadap Notaris.

h. Asas profesionalitas 
Volume 2 Nomor 2, Desember 2019

E-ISSN : 2655-7347

Notaris wajib memberikan pelayanan sesuai dengan ketentuan dalam peraturan perUndang-Undangan, kecuali ada alasan untuk menolaknya. Asas ini mengutamakan keahlian (keilmuan) Notaris dalam menjalankan tugas jabatannya.

Menurut Abdulkadir Muhammad, Notaris dalam menjalankan tugas jabatannya: ${ }^{2)}$

a) Notaris dituntut melakukan perbuatan akta dengan baik dan benar Artinya akta yang dibuat itu memenuhi kehendak hukum dan permintaan pihak-pihak yang berkepentingan karena jabatannya.

b) Notaris dituntut menghasilkan akta yang bermutu Artinya akta yang dibuatnya itu sesuai dengan aturan hukum dan kehendak pihak yang berkepentingan dalam arti yang sebenarnya. Notaris harus menjelaskan kepada pihak-pihak yang berkepentingan akan kebenaran isi dan prosedur akta yang dibuatnya itu.

c) Berdampak positif

Artinya siapapun akan mengakui akta Notaris itu mempunyai kekuatan bukti sempurna. Dalam kaitan ini Notaris tidak boleh secara sengaja melakukan hal yang dapat membuat akta autentik mempunyai kekuatan hanya sebagai akta di bawah tangan.

Tanggung Jawab Notaris dalam Undang-Undang No 2 Tahun 2014 Tentang Jabatan Notaris yaitu Pasal 65 yang menyatakan bahwa "Notaris, Notaris Pengganti, dan Pejabat sementara Notaris bertanggung jawab atas setiap akta yang dibuatnya meskipun Protokol Notaris telah diserahkan atau dipindahkan kepada pihak penyimpan Protokol Notaris". Kewenangan Notaris Dalam Pasal 15 Undang-Undang Nomor 2 Tahun 2014 tentang Jabatan Notaris memberikan kewenangan yang sangat luas kepada Notaris

2) Anshori, Lembaga Kenotariatan Indonesia: Perspektif Hukum dan Etika, hal.49. 
Volume 2 Nomor 2, Desember 2019

E-ISSN : 2655-7347

dalam bidang pembuatan akta, dalam mana terdapat klausul: "Semuanya itu sepanjang pembuatan akta itu tidak juga ditugaskan atau dikecualikan kepada pejabat lain atau orang lain yang ditetapkan oleh Undang-Undang." Kewenangan Notaris diatur pada bagian sendiri dalam Undang-Undang tentang Jabatan Notaris, yaitu Bab III Bagian Pertama, yaitu pada Pasal 15 Undang-Undang Nomor 2 Tahn 2014 tentang Jabatan Notaris yang menyatakan:

1) Notaris berwenang membuat akta autentik mengenai semua perbuatan, perjanjian, dan penetapan yang diharuskan oleh peraturan perUndangUndangan dan/atau yang dikehendaki oleh yang berkepentingan untuk dinyatakan dalam akta autentik, menjamin kepastian tanggal pembuatan akta, menyimpan akta, memberikan grosse, salinan dan kutipan akta, semuanya itu sepanjang pembuatan akta itu tidak juga ditugaskan atau dikecualikan kepada pejabat lain atau orang lain yang ditetapkan oleh Undang-Undang.

2) Selain kewenangan sebagaimana dimaksud pada Ayat (1), Notaris berwenang pula:

a. mengesahkan tanda tangan dan menetapkan kepastian tanggal surat di bawah tangan dengan mendaftar dalam buku khusus;

b. membukukan surat di bawah tangan dengan mendaftar dalam buku khusus;

c. membuat kopi dari asli surat di bawah tangan berupa salinan yang memuat uraian sebagaimana ditulis dan digambarkan dalam surat yang bersangkutan;

d. melakukan pengesahan kecocokan fotokopi dengan surat aslinya;

e. memberikan penyuluhan hukum sehubungan dengan pembuatan akta;

f. membuat akta yang berkaitan dengan pertanahan; atau

g. membuat akta risalah lelang.

3) Selain kewenangan sebagaimana dimaksud pada Ayat (1) dan Ayat (2), Notaris mempunyai kewenangan lain yang diatur dalam peraturan perUndang-Undangan.”

Menurut Black's Law Dictionary, sanksi atau dalam bahasa inggris disebut sanction adalah "Sanction is a penalty or other mechanism of 
Volume 2 Nomor 2, Desember 2019

E-ISSN : 2655-7347

enforcement used to provide incentives for obedience with the law or the rules and regulation. That part of a law which is designed to secure enforcement by imposing a penalty for its violation or offering a reward for its observance." Yang artinya yaitu Sanksi adalah hukuman atau mekanisme penegakan lain yang digunakan untuk memberikan insentif untuk kepatuhan dengan hukum atau peraturan dan regulasi. Bagian dari hukum yang dirancang untuk menjamin penegakan hukum dengan menjatuhkan hukuman atas pelanggarannya atau menawarkan hadiah atas ketaatannya.

Pasal 16 Ayat (1) huruf $M$ yang menyatakan Notaris dalam menjalankan jabatannya wajib membacakan akta di hadapan penghadap dengan dihadiri oleh paling sedikit 2 (dua) orang saksi, atau 4 (empat) orang saksi khusus untuk pembuatan akta wasiat di bawah tangan dan ditandatangani pada saat itu juga oleh penghadap, saksi, dan Notaris.

Kode Etik Notaris melalui Pasal 6 Ayat (1) menyatakan bahwa "Sanksi yang kenakan terhadap anggota yang melakukan pelanggaran Kode Etik dapat berupa Teguran, Peringatan, Pemberhentian sementara dari keanggotaan Perkumpulan, Pemberhentian dengan hormat dari keanggotaan Perkumpulan, dan Pemberhentian dengan tidak hormat dari keanggotaan Perkumpulan." Apabila seseorang dapat dikenakan pidana harus dapat dibuktikan adanya hal-hal yang melakukan perbuatan pidana yang bersifat melawan hukum, mampu bertanggung jawab (di atas umur yang telah ditentukan), mempunyai suatu bentuk kesalahan yang berupa kesengajaan atau kealpaan, tidak adanya alasan pemaaf (tidak ada alasan penghapus pidana).

Pasal 49 Ayat (2) yang menyatakan sebagai berikut: "Dalam hal suatu perubahan tidak dapat dibuat di sisi kiri Akta, perubahan tersebut dibuat pada akhir Akta, sebelum penutup Akta, dengan menunjuk bagian yang diubah atau dengan menyisipkan lembar tambahan".

Pasal 50 Ayat (1) yang menyatakan sebagai berikut: "Jika dalam Akta perlu dilakukan pencoretan kata, huruf, atau angka, pencoretan dilakukan sedemikian rupa sehingga tetap dapat dibaca sesuai dengan yang tercantum 
Volume 2 Nomor 2, Desember 2019

E-ISSN : 2655-7347

semula, dan jumlah kata, huruf, atau angka yang dicoret dinyatakan pada sisi kiri Akta'.

Pasal 51 Ayat (1) yang menyatakan sebagai berkut: "Notaris berwenang untuk membetulkan kesalahan tulis dan/atau kesalahan ketik yang terdapat pada Minuta Akta yang telah ditandatangani” Pasal 51 Ayat (2) yang menyatakan bahwa "Pembetulan sebagaimana dimaksud pada Ayat (1) dilakukan di hadapan penghadap, saksi, dan Notaris yang dituangkan dalam berita acara dan memberikan catatan tentang hal tersebut pada Minuta Akta asli dengan menyebutkan tanggal dan nomor Akta berita acara pembetulan".

Pasal 1869 KUHPerdata dimana tanda tangan para pihak adalah hal yang mutlak harus ada (dengan pengecualian adanya surrogate) pada suatu akta agar dapat memiliki kekuatan pembuktian sebagai akta bawah tangan.

\section{B. Hasil Wawancara}

Menurut Bapak Dr. Stanislaus Atalim S.H., M.H., pada dasarnya notaris sudah diatur dalam Undang-Undang Nomor 2 Tahun 2014 Tentang Jabatan Notaris, namun dalam kasus tersebut Notaris tidak mengikuti aturan dalam Undang-Undang yang sudah ditentukan. Notaris dalam melakukan perubahan isi akta harus dalam persetujuan para pihak dan isi akta tersebut harus dilakukan sesuai dengan Undang-Undang Nomor 2 Tahun 2014.

Tindakan Notaris tersebut selain melanggar ketentuan dalam UndangUndang Nomor 2 Tahun 2014 tentang Jabatan Notaris juga melanggar kewajiban yang dinyatakan dalam Pasal 3 angka 1, 2, dan 4. Pasal 3 angka 1 Kode Etik mewajibkan Notaris untuk memiliki moral, akhlak, serta kepribadian yang baik. Tindakan Notaris mengubah akta tanpa persetujuan dari salah satu pihak namun diketahui pihak lain menunjukkan kemungkinan adanya "permainan" antara Notaris dan pihak yang mengetahui perubahan tersebut. Tindakan Notaris tersebut menunjukkan bahwa Notaris X tidak memiliki moral, akhlak, dan kepribadian yang baik. Tindakan ini berdampak pada dilanggarnya kewajiban Notaris pada Pasal 3 angka 2 Kode Etik, yaitu kewajiban menghormati dan menjunjung tinggi harkat dan martabat Jabatan 
Volume 2 Nomor 2, Desember 2019

E-ISSN : 2655-7347

Notaris. Perbuatan tercela Notaris dapat merusak citra baik dan terhormat Notaris sebagai pejabat umum di hadapan masyarakat, akta Notaris yang seharusnya memiliki kekuatan pembuktian sempurna bisa kehilangan kepercayaan dari masyarakat dan berdampak pada tercorengnya nama baik korps Notaris.

Pelanggaran terhadap kewajiban Pasal 3 angka 4 yaitu Notaris tidak berperilaku jujur, mandiri, tidak berpihak, amanah, seksama, penuh rasa tanggung jawab, berdasarkan peraturan perundang-undangan dan isi sumpah jabatan Notaris. Notaris jelas tidak berperilaku sebagaimana diwajibkan Undang-Undang Jabatan Notaris yang mana pelanggaran terhadap ketentuanketentuannya telah dijabarkan pada bagian sebelumnya dan juga melanggar isi sumpah jabatan Notaris sebagaimana dinyatakan dalam Pasal 4 UndangUndang tentang Jabatan Notaris, dan lagi-lagi pelanggaran dilakukan terhadap sumpah untuk menjalankan jabatan dengan amanah, jujur, saksama, mandiri, dan tidak berpihak. Selain itu Notaris juga melanggar sumpah jabatan yaitu sumpah bahwa ia akan menjaga sikap, tingkah laku, dan akan menjalankan kewajiban sesuai kode etik profesi, kehormatan, martabat, dan tanggung jawab sebagai Notaris.

Dalam membuat akta partij, Notaris hanya perlu mencatatkan apa yang dikehendaki oleh para pihak dalam akta, sebagaimana dinyatakan sebagai kewenangan Notaris dalam Pasal 15 Ayat (1) Undang-Undang tentang Jabatan Notaris tanpa memiliki sedikit pun kewenangan untuk melakukan penyesuaian akta dengan inisiatif sendiri tanpa persetujuan para pihak dalam akta tersebut. Dalam akta partij, Notaris hanya membuat suatu cerita berdasarkan apa yang diterangkan atau diceritakan para pihak pada Notaris dalam menjalankan jabatannya dan untuk keperluan mana para pihak tersebut sengaja datang di hadapan Notaris, agar keterangan atau perbuatan itu dikonstatir Notaris dalam suatu akta autentik. Apabila Notaris hendak melakukan pengubahan, maka pengubahan atau renvoi itu harus dilakukan berdasarkan tata cara yang diwajibkan oleh Undang-Undang 
Volume 2 Nomor 2, Desember 2019

E-ISSN : 2655-7347

Sebagaimana dinyatakan oleh ahli hukum pidana yang dihadirkan dalam persidangan, pengubahan yang dilakukan oleh Notaris tanpa mengikuti syarat berdasarkan Undang-Undang mengakibatkan kekuatan pembuktian dari akta autentik menjadi lemah, dengan arti akta autentik tidak memiliki kekuatan mengikat lagi bahkan akan dapat dimintakan pertanggungjawaban pidana terhadap adanya pemalsuan surat. Dengan demikian jelas bahwa bukan hanya karena Notaris tidak mengubah untuk kepentingan dirinya atau kepentingan orang lain, tindakan pengubahan yang tidak sesuai dengan prosedur yang diwajibkan undang-undang dapat dibenarkan karena yang merupakan unsur utama dalam Pasal 264 Ayat (1) KUHP adalah tindakan memalsukan surat, suatu tindakan mengubah isi surat, dalam hal ini akta Notaris menjadi lain daripada sebagaimana seharusnya.

Pasal 16 Ayat (1) huruf M yang menyatakan Notaris dalam menjalankan jabatannya wajib membacakan akta di hadapan penghadap dengan dihadiri oleh paling sedikit 2 (dua) orang saksi, atau 4 (empat) orang saksi khusus untuk pembuatan akta wasiat di bawah tangan dan ditandatangani pada saat itu juga oleh penghadap, saksi, dan Notaris.

Pasal 49 Ayat (2) yang menyatakan sebagai berikut: "Dalam hal suatu perubahan tidak dapat dibuat di sisi kiri Akta, perubahan tersebut dibuat pada akhir Akta, sebelum penutup Akta, dengan menunjuk bagian yang diubah atau dengan menyisipkan lembar tambahan".

Pasal 50 Ayat (1) yang menyatakan sebagai berikut: "Jika dalam Akta perlu dilakukan pencoretan kata, huruf, atau angka, pencoretan dilakukan sedemikian rupa sehingga tetap dapat dibaca sesuai dengan yang tercantum semula, dan jumlah kata, huruf, atau angka yang dicoret dinyatakan pada sisi kiri Akta'.

Pasal 51 Ayat (1) yang menyatakan sebagai berkut: "Notaris berwenang untuk membetulkan kesalahan tulis dan/atau kesalahan ketik yang terdapat pada Minuta Akta yang telah ditandatangani” Pasal 51 Ayat (2) yang menyatakan bahwa "Pembetulan sebagaimana dimaksud pada Ayat (1) dilakukan di hadapan penghadap, saksi, dan Notaris yang dituangkan dalam 
Volume 2 Nomor 2, Desember 2019

E-ISSN : 2655-7347

berita acara dan memberikan catatan tentang hal tersebut pada Minuta Akta asli dengan menyebutkan tanggal dan nomor Akta berita acara pembetulan".

Pasal 1869 KUHPerdata dimana tanda tangan para pihak adalah hal yang mutlak harus ada (dengan pengecualian adanya surrogate) pada suatu akta agar dapat memiliki kekuatan pembuktian sebagai akta bawah tangan.

E. Kewajiban Notaris

Kewajiban Notaris diatur dalam Pasal 16 Ayat (1) Undang-Undang Nomor 2 Tahun 2014 tentang Jabatan Notaris, yaitu menyatakan sebagai berikut:

a. Bertindak amanah, jujur, saksama, mandiri, tidak berpihak, dan menjaga kepentingan pihak yang terkait dalam perbuatan hukum;

b. Membuat akta dalam bentuk minuta akta dan menyimpannya sebagai bagian dari protokol Notaris;

c. Melekatkan surat dan dokumen serta sidik jari penghadap pada minuta akta;

d. Mengeluarkan grosse akta, salinan akta, atau kutipan akta berdasarkan minuta akta;

e. Memberikan pelayanan sesuai dengan ketentuan dalam UndangUndang ini kecuali ada alasan untuk menolaknya;

f. Merahasiakan segala sesuatu mengenai akta yang dibuatnya dan segala keterangan yang diperoleh guna pembuatan akta sesuai dengan sumpah/janji jabatan, kecuali Undang-Undang menentukan lain;

g. Menjilid akta yang dibuatkan dalam 1 bulan menjadi buku yang memuat tidak lebih dari 50 akta, dan jika jumlah akta tidak dapat dimuat dalam satu buku, akta tersebut dapat dijilid menjadi lebih dari satu buku, dan mencatat jumlah minuta akta, bulan, dan tahun pembuatannya pada sampul setiap buku;

h. Membuat daftar dari akta protes terhadap tidak dibayar atau tidak diterimanya surat berharga;

i. Membuat daftar akta yang berkenaan dengan wasiat menurut urutan waktu pembuatan akta setiap bulan; 
Volume 2 Nomor 2, Desember 2019

E-ISSN : 2655-7347

j. Mengirimkan daftar akta sebagaimana dimaksud dalam huruf i atau daftar nihil yang berkenaan dengan wasiat ke pusat daftar wasiat pada kementerian yang menyelenggarakan urusan pemerintahan di bidang hukum dalam waktu 5 (lima) hari pada minggu pertama setiap bulan berikutnya;

k. Mencatat dalam reportorium tanggal pengiriman daftar wasiat pada setiap akhir bulan;

1. Mempunyai cap atau stempel yang memuat lambang negara Republik Indonesia dan pada ruang yang melingkarinya dituliskan nama, jabatan, dan tempat kedudukan yang bersangkutan;

m. Membacakan akta di hadapan penghadap dengan dihadiri oleh paling sedikit 2 (dua) orang saksi, atau 4 (empat) orang saksi khusus untuk pembuatan akta wasiat di bawah tangan, dan ditandatangani pada saat itu juga oleh penghadap, saksi, dan Notaris;

n. Menerima magang calon Notaris.

Beberapa kewajiban Notaris diatas memiliki pengecualian, diantaranya Pasal 16 Ayat (1) Ayat B yang mewajibkan Notaris membuat akta dalam bentuk minuta akta dan meyimpannya sebagai bagian dari protokol Notaris. Notaris berkewajiban untuk membuat dokumen atau akta yang diminta masyarakat. Ia tidak dapat menolak permohonan tersebut tanpa alasan yang jelas karena kewajiban pembuatan dokumen telah diamanatkan Undang-Undang. Hal ini sejalan dengan isi dari Pasal 16 Ayat (1) huruf E Undang-Undang Nomor 2 Tahun 2014 tentang Jabatan Notaris sebagaimana telah dijabarkan di atas. Penjelasan Ayat tersebut secara lengkap menyatakan bahwa "Yang dimaksud dengan "alasan untuk menolaknya" adalah alasan yang mengakibatkan Notaris tidak berpihak, seperti adanya hubungan darah atau semenda dengan Notaris sendiri atau dengan suami/istrinya, salah satu pihak tidak mempunyai kemampuan bertindak untuk melakukan perbuatan, atau hal lain yang tidak dibolehkan UndangUndang." Dengan demikian jelas bahwa apabila Notaris menolak untuk memberikan jasanya pada pihak yang membutuhkan, maka penolakan tersebut harus merupakan penolakan dalam arti hukum, yang memiliki alasan 
Volume 2 Nomor 2, Desember 2019

E-ISSN : 2655-7347

atau argumentasi hukum yang jelas dan tegas sehingga pihak yang bersangkutan dapat memahaminya.

\section{Analisis}

Dalam kasus ini, Daniel adalah pihak yang dapat melakukan tanda tangan dan paraf sebagaimana tampak dalam minuta akta yang dimiliki Notaris yang terdapat tanda tangan asli dari Daniel. Hal ini menunjukkan bahwa apabila terdapat renvoi dalam akta yang salah satu pihaknya adalah Daniel, maka Daniel wajib mengetahui dan memberi persetujuan dengan membubuhkan paraf untuk renvoi tersebut. Pengubahan yang dilakukan Notaris pada Pasal 4 Akta Nomor 149 mengakibatkan adanya pengubahan pihak yang menjadi penanggung jawab dalam pelaksanaan proyek, Pasal 6 dan Pasal 9 yang berubah merupakan garis lurus dengan perubahan Pasal 4 yang menunjukkan bahwa Bonar dan Mangapul yang menjadi pelaksana utama proyek tersebut sementara Daniel menjadi kehilangan haknya untuk menjadi penanggung jawab proyek sebagaimana diperjanjikan pada awal dibuatnya perjanjian kerja sama. Pengubahan (pembetulan) dalam akta atau yang dikenal dengan istilah renvoi dapat dilakukan sebelum penandatanganan akta atau setelah penandatanganan akta dilakukan. Pasal 48, Pasal 49, dan Pasal 50 menunjukkan cara melakukan renvoi pada saat akta belum ditandatangani terhadap akta yang sudah ditandatangani, maka pengubahannya harus tunduk pada Pasal 51 Undang-Undang Nomor 2 Tahun 2014 tentang Jabatan Notaris.

Dalam kasus ini, Notaris melakukan pengubahan setelah akta ditandatangani kedua belah pihak sehingga Notaris harus mengikuti prosedur pada Pasal 51, yaitu ia harus memanggil para pihak dan saksi pada saat penandatanganan akta dan melakukan pembetulan yang diinginkan dan mencatatkan hal tersebut pada minuta akta asli, yaitu akta perjanjian kerja sama nomor 149 tanggal 30 Maret 2011 dengan menyebutkan tanggal dan nomor akta berita acara pembetulan. Apabila Notaris tetap berpendirian bahwa pengubahan telah dilakukan sebelum dilakukan tanda tangan minuta oleh para pihak, termasuk Daniel, maka pengubahan (renvoi) seharusnya 
Volume 2 Nomor 2, Desember 2019

E-ISSN : 2655-7347

dilakukan sesuai dengan ketentuan Pasal 48, Pasal 49, dan Pasal 50 Undangundang tentang Jabatan Notaris, yaitu pada pengubahan hanya dapat dilakukan dengan pencoretan yang dilakukan sedemikian rupa sehingga tetap dapat dibaca sesuai dengan yang tercantum semula, dan jumlah kata, huruf, atau angka yang dicoret dinyatakan pada sisi kiri akta, yaitu dalam kasus ini pada sisi kiri Pasal 4, Pasal 6, dan Pasal 9 Akta Nomor 149. Pencoretan ini harus diikuti paraf oleh para pihak, yaitu Daniel selaku pihak pertama dan Bonar serta Mangapul selaku pihak kedua sebagai bentuk persetujuan masing-masing atas perubahan tersebut.

Pelanggaran atas Pasal 48, Pasal 49, dan Pasal 50 tersebut mengakibatkan Akta Nomor 149 hanya memiliki kekuatan pembuktian sebagai akta di bawah tangan dan dapat menjadi alasan bagi pihak yang menderita kerugian untuk menuntut penggantian biaya, ganti rugi, dan bunga kepada Notaris, hal mana telah dilakukan oleh Daniel dan sampai saat ini perkara tersebut masih bergulir. Perlu ditekankan bahwa Akta nomor 149 yang dibuat oleh Notaris merupakan akta partij, yang merupakan akta yang dibuat di hadapan Notaris, Notaris membuat suatu cerita berdasarkan perbuatan yang dilakukan pihak lain di hadapan Notaris, yaitu berdasarkan apa yang diterangkan atau diceritakan oleh pihak lain kepada Notaris dalam menjalankan jabatannya dan untuk keperluan mana pihak lain itu sengaja datang di hadapan Notaris, agar keterangan atau perbuatan itu dikonstatir oleh Notaris dalam suatu akta autentik.

Akta yang dibuat oleh Notaris merupakan perjanjian antara Daniel selaku pihak pertama dengan Mangapul dan Bonar selaku pihak kedua, sehingga akta nomor 149 tersebut harus memenuhi unsur sepakat yang merupakan salah satu syarat subjektif sahnya perjanjian. Sepakat memiliki pengertian pernyataan kehendak beberapa orang, artinya perjanjian hanya dapat timbul dengan kerja sama dari dua orang atau lebih atau perjanjian “dibangun" oleh perbuatan dari beberapa orang.

Dengan demikian jelas bahwa Notaris hanya merupakan perantara antara para pembuat perjanjian yang memiliki kesepakatan, yaitu Daniel dan 
Volume 2 Nomor 2, Desember 2019

E-ISSN : 2655-7347

Bonar serta Mangapul, yang bertanggung jawab dan berwenang atas pengaturan isi dari akta nomor 149 adalah para pihak dan Notaris tidak memiliki kewenangan sama sekali untuk melakukan pengubahan terhadap isi akta tanpa persetujuan para pihak. Selain pelanggaran di atas, Notaris juga telah melakukan beberapa pelanggaran lain. Pertama terhadap Pasal 16 Ayat (1), dimana Notaris yang bersangkutan tidak bertindak amanah, jujur, saksama, mandiri, tidak berpihak, dan menjaga kepentingan pihak yang terkait dalam perbuatan hukum. Amanah diartikan sebagai sesuatu yang dipercayakan atau dititipkan kepada orang lain, dapat dipercaya, setia. Notaris sudah dipercaya oleh para pihak untuk membuat perjanjian kerja sama, namun Notaris malah mengubah akta tanpa sepengetahuan salah satu pihak yang akhirnya mengalami kerugian, sehingga Tindakan Notaris ini dapat mencoreng nama Notaris.

Notaris tidak bertindak dengan saksama karena pada awalnya Notaris yang bersangkutan melakukan kesalahan dengan salah mencantumkan pihak yang seharusnya mendapatkan prestasi, hal ini kemudian yang diminta oleh Daniel untuk diperbaiki. Selain itu teknik perbaikan akta yang dilakukan Notaris yang tidak sesuai dengan Undang-undang tentang Jabatan Notaris menunjukkan bahwa Notaris tidak saksama dalam mengerjakan perbaikan dalam akta. Notaris tidak bertindak secara mandiri dan tidak berpihak.

Hal ini dapat disimpulkan dari adanya perbedaan jenis akta yang diberikan pada para pihak. Kepada Daniel selaku Pihak Pertama hanya diberikan print-an draft perjanjian kerja sama oleh pegawai Notaris saat Daniel meminta salinan minuta akta dengan alasan salinan belum selesai dan Notaris sedang di luar kota, sementara Bonar dan Mangapul selaku Pihak Kedua memperoleh salinan akta sesuai minuta padahal menurut Pasal 16 Ayat (1) huruf D Undang-Undang Nomor 2 Tahun 2014 Tentang Jabatan Notaris, Notaris diwajibkan mengeluarkan Grosse Akta, Salinan Akta, atau Kutipan Akta.

Kode Etik Notaris melalui Pasal 6 Ayat (1) menyatakan bahwa "Sanksi yang kenakan terhadap anggota yang melakukan pelanggaran Kode Etik 
Volume 2 Nomor 2, Desember 2019

E-ISSN : 2655-7347

dapat berupa Teguran, Peringatan, Pemberhentian sementara dari keanggotaan Perkumpulan, Pemberhentian dengan hormat dari keanggotaan Perkumpulan, dan Pemberhentian dengan tidak hormat dari keanggotaan Perkumpulan." Apabila seseorang dapat dikenakan pidana harus dapat dibuktikan adanya hal-hal yang melakukan perbuatan pidana yang bersifat melawan hukum, mampu bertanggung jawab (di atas umur yang telah ditentukan), mempunyai suatu bentuk kesalahan yang berupa kesengajaan atau kealpaan, tidak adanya alasan pemaaf (tidak ada alasan penghapus pidana).

Ketentuan-ketentuan di atas secara eksplisit menyatakan bahwa yang harus diterima oleh pihak yang berkepentingan langsung, dalam hal ini Daniel adalah salinan akta, dan undang-undang tidak mengenal adanya istilah printan draft minuta akta yang belum ditandatangani sehingga akta yang disebut belakangan tidak memiliki kekuatan pembuktian autentik, dan pada print-an draft tersebut juga tidak terdapat tanda tangan para pihak, saksi-saksi dan Notaris seperti minuta akta atau setidaknya tanda tangan Notaris dan stempel Notaris yang menunjukkan keautentikan akta tersebut sebagai suatu salinan sesuai asli. Dengan demikian print-an draft yang diterima oleh Daniel tidak memiliki kekuatan pembuktian selaku akta autentik dan bahkan tidak memiliki kekuatan pembuktian di bawah tangan jika mengacu pada Pasal 1869 KUHPerdata dimana tanda tangan para pihak adalah hal yang mutlak harus ada (dengan pengecualian adanya surrogate) pada suatu akta agar dapat memiliki kekuatan pembuktian sebagai akta bawah tangan. Hal ini berdampak pada saat pengajuan kasus ini secara perdata dengan dalil wanprestasi dimana Daniel mendasarkan perbuatan pengurusannya akan proyek pada print-an draft minuta akta dan Bonar dan Mangapul menggunakan salinan minuta akta.

Meskipun dalam persidangan tidak terungkap fakta bahwa Notaris dan Bonar serta Mangapul sama-sama merencanakan pengubahan ini, namun ketidakmandirian dan ketidakberpihakan Notaris dapat dilihat dari adanya gugatan Bonar dan Mangapul pada Daniel dengan menggunakan salinan akta 
Volume 2 Nomor 2, Desember 2019

E-ISSN : 2655-7347

perjanjian kerja sama yang sudah dilakukan pengubahan dimana Daniel sama sekali tidak mengetahui pengubahan terhadap beberapa pasal tersebut. Perbuatan Notaris demikian juga sekaligus menunjukkan adanya pelanggaran terhadap kewajiban Notaris untuk menjaga kepentingan para pihak dalam akta dimana kepentingan Daniel menjadi terganggu dengan adanya pengubahan yang dilakukan oleh Notaris tersebut.

Sebagaimana dinyatakan oleh ahli hukum pidana yang dihadirkan dalam persidangan, pengubahan yang dilakukan oleh Notaris tanpa mengikuti syarat berdasarkan Undang-Undang mengakibatkan kekuatan pembuktian dari akta autentik menjadi lemah, dengan arti akta autentik tidak memiliki kekuatan mengikat lagi bahkan akan dapat dimintakan pertanggungjawaban pidana terhadap adanya pemalsuan surat. Dengan demikian jelas bahwa bukan hanya karena Notaris tidak mengubah untuk kepentingan dirinya atau kepentingan orang lain, tindakan pengubahan yang tidak sesuai dengan prosedur yang diwajibkan undang-undang dapat dibenarkan karena yang merupakan unsur utama dalam Pasal 264 Ayat (1) KUHP adalah tindakan memalsukan surat, suatu tindakan mengubah isi surat, dalam hal ini akta Notaris menjadi lain daripada sebagaimana seharusnya.

Dengan demikian, Penulis menyimpulkan bahwa Kesalahan Notaris bukan sekedar kesalahan yang bisa diperbaiki dan tidak menimbulkan kerugian materiil maupun imateriil bagi para pihak namun sudah menimbulkan kerugian imateriil yang cukup besar pada Daniel.

\section{PENUTUP}

\section{A. Kesimpulan}

Berdasarkan pokok masalah yang diajukan, maka dapat disampaikan kesimpulan dan saran sebagai berikut:

A. Notaris sebagai pejabat umum sebagaimana diamanatkan oleh Undang-Undang Republik Indonesia Nomor 2 Tahun 2014 Tentang Perubahan Atas Undang-Undang Nomor 30 Tahun 2004 Tentang Jabatan Notaris hanya memiliki kewenangan untuk 
Volume 2 Nomor 2, Desember 2019

E-ISSN : 2655-7347

mengkonstantir kehendak para pihak (penghadap) yang disampaikan kepadanya ke dalam bentuk suatu akta autentik, baik dalam pembuatan akta partij maupun akta relaas. UndangUndang Republik Indonesia Nomor 2 Tahun 2014 Tentang Perubahan Atas Undang-Undang Nomor 30 Tahun 2004 Tentang Jabatan Notaris juga telah mewajibkan Notaris meminta cap jari penghadap guna kepentingan kepastian dan jaminan bagi Notaris yang membuat akta tersebut. Dengan adanya tanda tangan dan cap jarinya, para penghadap seakan ingin mempertegas apa yang ada dalam akta memang merupakan kehendak dan tanggung jawab mereka. Hal ini secara eksplisit melarang Notaris untuk melakukan pengubahan terhadap konten yang ada dalam akta setelah ditandatangani para penghadap, kecuali dengan melalui prosedur sebagaimana diwajibkan oleh ketentuan yang berlaku.

\section{B. Saran}

Kementerian Hukum dan Hak Asasi Manusia Republik Indonesia sebagai pihak yang memegang tanggung jawab pengawasan terhadap Notaris hendaknya mengeluarkan suatu peraturan yang memberi batasan-batasan konkrit kepada Majelis Pengawas di masing-masing tingkatan dalam menjatuhkan sanksi, misalnya terkait perbuatan Notaris yang bagaimana yang layak diberi sanksi teguran lisan, lalu tingkat berikutnya, tindakan bagaimana yang memungkinkan Notaris dikenakan sanksi teguran lisan, dan seterusnya sehingga sanksi disini dapat digunakan untuk menciptakan suatu keadilan yang dalam ranah hukum pidana dikenal dengan sebutan keadilan restoratif.

\section{DAFTAR PUSTAKA}

A. Buku

Adjie, Habib dan Sjaifurrachman, Aspek Pertanggungjawaban Notaris dalam Pembuatan Akta (Bandung: Mandar Maju, 2011). 
Volume 2 Nomor 2, Desember 2019

E-ISSN : 2655-7347

Adjie, Habib, Kebatalan dan Pembatalan Akta Notaris, (Bandung: PT Refika Aditama, 2011).

Anshori, Lembaga Kenotariatan Indonesia: Perspektif Hukum dan Etika.

Budiono, Herlin, Ajaran Umum Hukum Perjanjian dan Penerapannya di

Bidang Kenotariatan, (Bandung: PT Citra Aditya Bakti, 2014).

Badrulzaman, Mariam Darus, Hukum Perikatan dalam KUHPerdata Buku

Ketiga, (Bandung: PT Citra Aditya Bakti, 2015).

Budiono, Herlien, "Pertanggung jawaban Notaris Berdasarkan Undang-

Undang Nomor 30 Tahun 2004," Renvoi Nomor 28 (September 2005).

Chazawi, Adami dan Ardi Ferdian, Tindak Pidana Pemalsuan (Jakarta: PT Raja Grafindo Persada, 2016).

G. H. S. Lumban Tobing, Peraturan Jabatan Notaris, (Jakarta: Erlangga, 1999).

Kie, Studi Notariat (Beberapa Pelajaran) dan Serba-serbi Praktek Cetakan Ke-I.

Muhammad, Abdulkadir, Etika Profesi Hukum, (Bandung: PT Citra Aditya Bakti, 2001).

Mertokusumo, Sudikno. Hukum Acara Perdata Indonesia. Cetakan ke-7. (Yogyakarta: Liberty, 2006).

Nieuwenhuis. Pokok-pokok Hukum Perikatan, terjemahan Djasadin Saragih, (Surabaya: Universitas Airlangga, 1985).

Soekanto, Soerjono, Pengantar Penelitian Hukum, Cetakan ke-3, (Jakarta: UI Press, 1986).

Santoso, Djohari dan Achmad Ali, Hukum Perjanjian Indonesia. (Yogyakarta: Fakultas Hukum Universitas Islam Indonesia 1983).

Satrio, J. Hukum Perjanjian. (PT. Citra Aditya Bakti, Bandung, 1992.).

Soekanto, Soerjono. Kamus Sosiologi. (Depok: Raja Grafindo Persada, 1993).

. Pengantar Penelitian Hukum. Cetakan ke-3 (Jakarta:

Universitas Indonesia Press, 1986).

Subekti, R. Hukum Perjanjian. (Jakarta: PT Intermasa, 2001). 
Volume 2 Nomor 2, Desember 2019

E-ISSN : 2655-7347

Patrick, Purwahid. Dasar-Dasar Hukum Perikatan (Perikatan yang Lahir dari Perjanjian dan UndangUndang), (Bandung: Mandar Maju, 1994).

Wignjosoebroto, Soerandyo, Profesi Profesionalisme dan Etika Profesi, (Jakarta: Media Notariat, 2001).

\section{B. Perundang-Undangan}

Indonesia, Republik. Undang-Undang Nomor 2 Tahun 2014 Tentang Perubahan Atas Undang-Undang Nomor 30 Tahun 2004 Tentang Jabatan Notaris. (Jakarta: MenKumHAM, 2014).

\section{Putusan}

Putusan Pengadilan Mahkamah Agung Nomor: 1003 K/PID/2015.

\section{Kamus}

Bahasa, Pusat. Kamus Besar Bahasa Indonesia. (Jakarta: Gramedia Pustaka Utama, 2008). 